\title{
RESEARCH
}

Open Access

\section{Relation between GSTP1 polymorphism and oxidative stress in patients with hepatocellular carcinoma}

\author{
Shaimaa Gamal Hassan Elofey ${ }^{1}$, Nevine F. Shafik ${ }^{2}$, Noha Hassan Radwan ${ }^{2 *}$ (D, Osman Mohammed Mansour ${ }^{3}$,
} Rasha Mahmoud Allam ${ }^{4}$ Samia Shouman ${ }^{5}$ and Iman Attia AbdelGawad ${ }^{2}$

\begin{abstract}
Background: Glutathione can reduce the oxidative stress by converting the unstable to stable molecules and its status in hepatocellular carcinoma (HCC) is correlated with tumor growth and metastasis.

Glutathione S-transferase Pi (GSTP1) is reported to detoxify the xenobiotic substrates by catalyzing their conjugation to reduced glutathione (GSH) and its over-expression was demonstrated in the early stages of HCC, while loss of GSTP1 has been suggested to increase the risk of deoxyribonucleic acid (DNA) damage and mutation.

The aim of this study is to assess the relationship of GSTP1 polymorphism lle105Val (rs1695 A > G) with HCC risk, and to investigate the oxidative stress status of HCC patients by measuring the antioxidant glutathione (GSH) levels. This study was conducted on 99 newly diagnosed HCC patients and 80 apparently healthy individuals as a normal control group.

All participants were subjected to the measurement of plasma GSH levels according to Ellman's method, and polymerase chain reaction-restriction fragment length polymorphism (PCR-RFLP) for the detection of GSTP1 polymorphismlle105Val (rs1695 A > G).
\end{abstract}

Results: The occurrence of either the mutant homozygous or the mutant heterozygous genotype of GSTP1 was significantly higher in HCC patients, while the occurrence of the wild genotype was significantly higher among the normal control subjects.

Mutant GSTP1 genotype, older age, male gender, and high serum alanine aminotransferase (ALT) were associated with increased risk of development of HCC.

The best sensitivity, specificity, PPV (positive predictive value), NPV (negative predictive value), and overall diagnostic performance for plasma GSH at a cutoff level of $2003.5 \mu \mathrm{M} / \mathrm{mg}$ were $57.6 \%, 52.5 \%, 60 \%$, and $40 \%$. The area under the curve for GSH was 0.562.

Conclusion: Mutant GSTP1 genotype was an independent prognostic factor for increased HCC risk which can be used in a risk assessment model for HCC.

Plasma GSH presents insufficient sensitivity and specificity for HCC.

Keywords: HCC, Glutathione, GSTP1

\footnotetext{
* Correspondence: nradwan5@hotmail.com

${ }^{2}$ The Department of Clinical and Chemical Pathology, $\mathrm{NCl}$, Cairo, Egypt

Full list of author information is available at the end of the article
}

\section{Springer Open}

(c) The Author(s). 2020 Open Access This article is licensed under a Creative Commons Attribution 4.0 International License, which permits use, sharing, adaptation, distribution and reproduction in any medium or format, as long as you give appropriate credit to the original author(s) and the source, provide a link to the Creative Commons licence, and indicate if changes were made. The images or other third party material in this article are included in the article's Creative Commons licence, unless indicated otherwise in a credit line to the material. If material is not included in the article's Creative Commons licence and your intended use is not permitted by statutory regulation or exceeds the permitted use, you will need to obtain permission directly from the copyright holder. To view a copy of this licence, visit http://creativecommons.org/licenses/by/4.0/. 


\section{Background}

Liver cancer was the sixth most commonly diagnosed cancer and the fourth leading cause of cancer death worldwide in 2018, with about 841,000 new cases and 782,000 deaths annually [1]. It is a major health problem with an increasing incidence in Egypt where it constitutes for $33.63 \%$ and $13.54 \%$ of all cancers in males and females respectively [2].

Both the immune response to viral hepatitis infection and oxidative stress are involved in the pathogenesis of HCC [3].

Storage of cysteine, anti-oxidant defense, and modulation of cell growth are some of the critical cellular functions induced by glutathione which is the main non-protein thiol in the mammalian cells. In HCC, GSH status is correlated with cellular proliferation, tumor growth, and metastasis [4].

There are 2 forms for glutathione: reduced (GSH) and oxidized (GSSG). The thiol group of cysteine in the reduced form is capable of donating a reducing equivalent $\left(\mathrm{H}^{+}+\mathrm{e}^{-}\right)$to other unstable molecules, including reactive oxygen species. Donating an electron converts glutathione to the reactive state. This reactive glutathione can react with another reactive glutathione to form glutathione disulfide (GSSG), which can then be catalyzed by the enzyme glutathione reductase (GSR) to regenerate GSH [5]. That is how GSH can reduce the oxidative stress by converting the unstable to stable molecules.

Glutathione $S$-transferases (GSTs) family is composed of eight isoforms that are known to detoxify the xenobiotic substrates by catalyzing their conjugation to GSH. Glutathione S-transferase P1 (GSTP1) is the most studied isoform in cancer. GSTP1 over-expression was demonstrated in early stages of HCC [6], while loss of GSTP1 has been suggested to increase the risk of DNA damage and mutation [7].

Since GSTP1 was reported to protect cells from the effects of cytotoxic and carcinogenic agents, we suggest that GSTP1 polymorphism might be a risk factor for the development of HCC supported by some studies that reported the association between GSTP1 polymorphism and some types of cancer, including esophageal and colorectal cancer [8].

The aim of this study is to assess the relationship of GSTP1 polymorphism Ile105Val (rs1695 A > G) with HCC risk, and to study the relationship of the GSTP1 polymorphism with some clinico-pathological factors of HCC. Investigating the oxidative stress status of HCC patients by measuring the antioxidant glutathione (GSH) levels and assessing the relation between the glutathione level and the expression of GSTP1 were done.

\section{Methods}

This study was approved from the ethical committee of the research institute Cairo University (Organization no.
0003381) under the number of 00004025 with a Federalwide Assurance (FWA) number 00007284 as well as the National Liver Institute-Shebein El-Kawm-El Monofeya. Written informed consent was obtained from all participants prior to inclusion in the study. This work was carried out in accordance with the Declaration of Helsinki for experiments involving humans.

This study was conducted on 99 newly diagnosed HCC patients who presented to the outpatients' clinic of the surgical oncology department over a period of consecutive 22 months from November 2014 to August 2016. All patients were below the age of 57 years. They were proven to have HCC by computed tomography, magnetic resonance imaging with typical findings of HCC, or with biopsy. They were included in this study prior to any therapeutic intervention. Patients with any other concomitant malignancy or under medical or surgical treatment were excluded. The study also included 80 apparently healthy volunteers below the age of 57 years as a normal control group. They were 60 males and 20 females. Their age ranged from 34 to 56 years. Both groups were age and sex matched.

All patients and control subjects were subjected to the following:

1. Careful history taking and clinical examination for patients.

2. Routine laboratory investigations: Complete blood count $(\mathrm{CBC})$, liver functions tests, lactate dehydrogenase (LDH), urea, creatinine, prothrombin time (PT) and concentration (PC), and international normalized ratio (INR).

3. AFP (Alpha feto-protein) was done using ARCHIT ECT i1000SR chemiluminescent micro particle Immunoassay (CMIA) Analyzer, Abbott, USA. The ARCHITECT AFP assay is designed to have an imprecision of $\leq 7.5 \%$ within-laboratory (total) $\%$ $\mathrm{CV}$ for samples between 10 and $2000 \mathrm{ng} / \mathrm{mL}$ and an $\mathrm{SD}$ of $\leq 0.75$ for samples less than $10 \mathrm{ng} / \mathrm{mL}$ down to the $\mathrm{LoQ}$ (i.e., $2.0 \mathrm{ng} / \mathrm{mL}$ ).

4. Measurement of plasma GSH levels by spectrophotometry: Measurement of plasma GSH levels was done using spectrophotometry according to Ellman's method. This method depends on the reduction of thiol reagent; Ellman's reagent (5, 5' -dithiobis-(2-nitrobenzoic acid)) or (DNTB) by the sulfhydryl SH group in the GSH to form the yellow chromophore; 5-thiontrobenzoic acid, measured spectrophotometrically at $412 \mathrm{~nm}$. Precipitation of protein thiols by trichloroacetic acid (TCA) was carried out before the addition of Ellman's reagent. In a 10-ml glass centrifuge tube, $500 \mu \mathrm{l}$ of heparinized blood was mixed well with $25 \mu \mathrm{l}$ trichloroactic acid. The tubes were then 
centrifuged at $3000 \mathrm{rpm}$ for $10 \mathrm{~min}$ at $4{ }^{\circ} \mathrm{C}$. One hundred microliter of the resultant supernatant was mixed thoroughly with $850 \mu$ lof phosphate buffer, followed by addition of $50 \mu \mathrm{l}$ Elleman's reagent. After $5 \mathrm{~min}$, the absorbance was measured spectrophotometrically at $412 \mathrm{~nm}$ against blank containing $100 \mu \mathrm{l}$ distilled water. Plasma glutathione (GSH) content was calculated in comparison with GSH standard curve [9].

5. PCR-RFLP for the detection of GSTP1 polymorphism:

- Total genomic DNA was extracted from peripheral blood samples of patients with HCC and control subjects using QIAamp DNA mini isolation kit (QIAGEN) following standard procedures according to the manufacturer's instructions.

- Genotyping of GSTP1 gene polymorphism Ile105Val (rs1695 A > G) was identified by polymerase chain reaction amplification and restriction fragment length polymorphism analysis (PCR-RFLP) [10]. The primers used were (5'-GTA GTTTGCCCA AGG TGAAG-3') as a forward primer and (5'-AGCCAC CTGAGGGGTAAG-3') as a reverse primer.

- PCR was conducted with 100 ng of genomic DNA, $2.5 \mu \mathrm{l}$ of $10 \times$ PCR buffer (Invitrogen, Carslbad, CA, USA), $0.25 \mu \mathrm{l}$ of Taq DNA polymerase (Invitrogen, Carslbad, CA, USA), $1 \mu$ of $10 \mathrm{mM} /$

Ideoxyribonucleosides triphosphates (dNTPs) (Promega, Madison, WI, USA), and $1.5 \mu \mathrm{l}$ of 10 $\mathrm{pmol} / \mathrm{ul}$ of each primer. PCR was performed with 35 cycles of the following, $95^{\circ} \mathrm{C}$ for $1 \mathrm{~min}$, followed by denaturation at $95^{\circ} \mathrm{C}$ for $45 \mathrm{~s}$, annealing at $60^{\circ} \mathrm{C}$ for $45 \mathrm{~s}$, and extension at $72^{\circ} \mathrm{C}$ for $1 \mathrm{~min}$, with a final extension at $72{ }^{\circ} \mathrm{C}$ for $10 \mathrm{~min}$. This resulted in one band at $433 \mathrm{bp}$ (Fig. 1).

- Digestion of the PCR product with $10 \mathrm{U}$ of Alw26 I (BsmAI) (New England Biolabs, USA) restriction enzyme in a final volume of $20 \mu \mathrm{l}$ incubated at $37^{\circ} \mathrm{C}$ overnight. The wild type genotype (I/I) produced a double band at 329 and $104 \mathrm{bp}$, whereas heterozygotes alleles (I/V) produced four bands at 329, 222, 107, and 104 bp. The homozygous polymorphic genotype $(\mathrm{V} / \mathrm{V})$ produced three bands at 222, 107, and $104 \mathrm{bp}$. Polymorphism was detected in $3 \%$ agarose gel (Fig. 2).

\section{Statistical methods}

Data were analyzed using IBM SPSS advanced statistics, version 22 (SPSS Inc., Chicago, IL). Numerical data were described as median and range, while qualitative data were described as numbers and percentages. Chi-square (Fisher's exact) test was used to examine the relation between qualitative variables as appropriate. Odds ratio was calculated using multiple logistic regression to assess the relationship of GSTP1 polymorphism with the HCC risk. Testing for normality was done using Kolmogorov-Smirnov test and Shapiro-Wilk test. Mann Whitney $U$ test was used to compare median values of variables that were not normally distributed between 2 independent groups.

Comparing the median values of more than two independent groups was tested using Kruskal-Wallis test.

Receiver operating characteristics (ROC) curve was done to estimate the best cutoff point, then calculation of sensitivity, specificity, PPV, and NPV with their 95\% confidence interval was done.

A $p$ value $\leq 0.05$ was considered significant. All tests were two tailed.

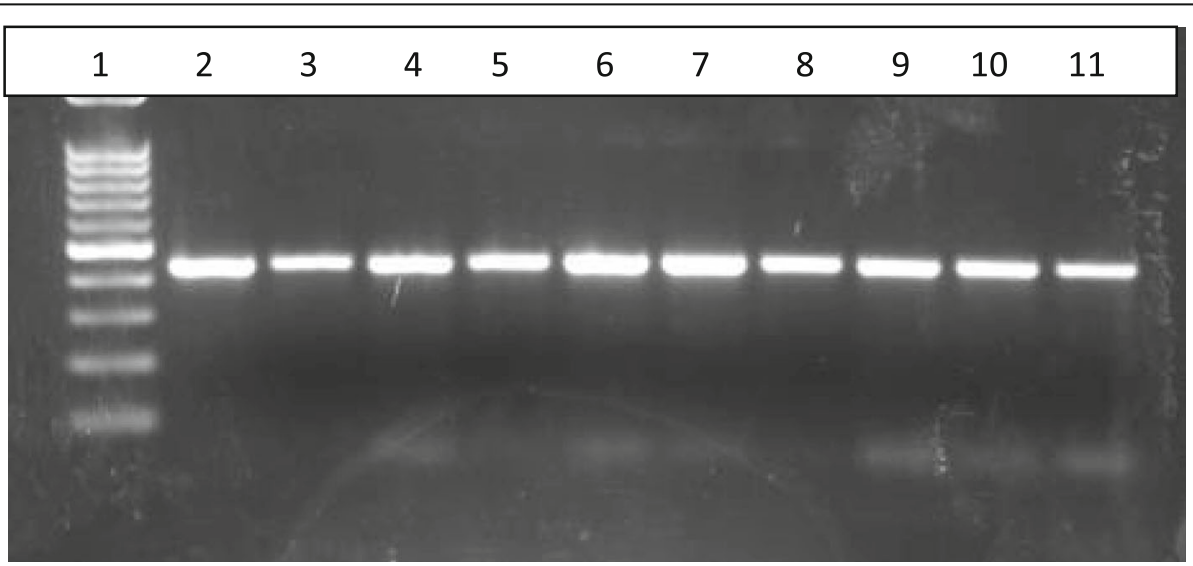

Fig. 1 PCR product on agarose gel before digestion appearing as bands at 433 base pair on electrophoresis (lanes 2-11). Molecular weight marker (100 bp) (lane 1) 


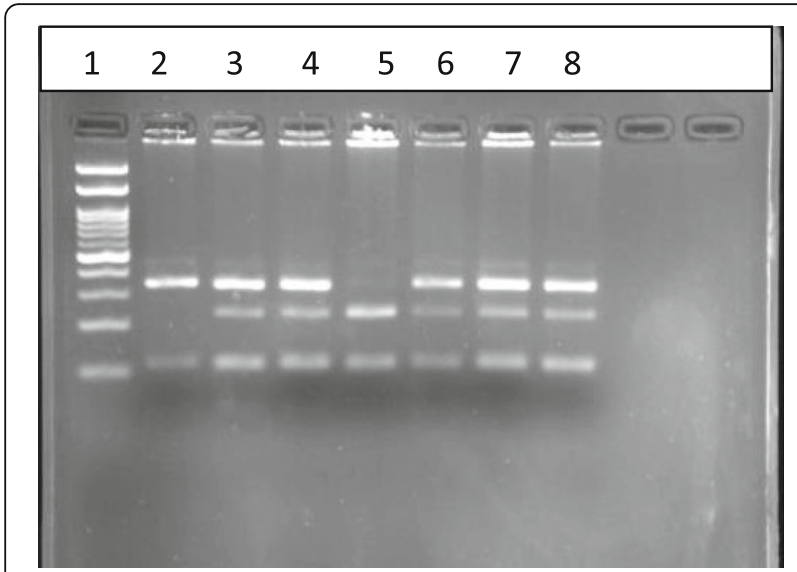

Fig. 2 Digestion using ALW261 illustrated by agarose gel electrophoresis. Molecular weight marker (100 bp) (lane 1). Wild phenotype: If DNA is cut as 2 bands at 329 and 104 base pair (case 1) (lane 2). Mutant homozygous phenotype: If DNA is cut as 2 bands at 222 and 107or 104 base pair (case 4) (lane 5). Mutant

heterozygous phenotype: If DNA is cut as 3 bands at 329, 222, and 107 or 104 base pair (case 2, 3, 5, 6, 7) (lanes 3, 4, 6, 7, 8)

\section{Results}

Patients' characteristics are mentioned in Table 1.

The comparison between the HCC and normal control groups as regards GSTP1 phenotype shows that the frequency of GSTP1 GA and GG genotype were significantly higher in HCC patients compared to the normal control subjects $(p=0.001)$. The frequency of the homozygous GG genotype was also significantly higher in HCC patients compared to the normal control subjects $(p=0.003)$ (Table 2).

Only the Child score (A), and absence of ascites were significantly associated with higher levels of plasma GSH ( $p$ value $=0.043$ each) (Table 3$)$.

The comparison between the $\mathrm{HCC}$ and the normal control groups as regards different laboratory markers and plasma GSH reveals the presence of significant differences between both groups regarding ALT, aspartate transaminase (AST), alkaline phosphatase (ALP), albumin, urea, LDH, INR, hemoglobin (HB), total leucocyte count (TLC), and platelet count $(p<0.001)$ each, while no significant differences were found as regards $\mathrm{GSH}$ levels $(p=0.152)$ (Table 4$)$.

The association of the different genotypes of GSTP1 with some prognostic factors of HCC as age, gender, tumor size, number of focal lesions, stage, Child score, distant metastasis, portal vein thrombosis (PVT), splenomegaly, cirrhosis, ascites, lymph node metastasis, viral infection, and family history using chi-square test revealed non-significant results except for portal vein thrombosis which showed a significant association with GSTP1 genotype $(p=0.00783)$ (Table 5).
Table 1 Descriptive analysis of HCC patients' characteristics

\begin{tabular}{|c|c|c|}
\hline Character & & No. (\%) $(\boldsymbol{N}=99)$ \\
\hline \multirow[t]{2}{*}{ Age (years) } & $<54$ & $55(55.6)$ \\
\hline & $55-56$ & $44(44.4)$ \\
\hline \multirow[t]{2}{*}{ Gender } & Female & $24(24.2)$ \\
\hline & Male & 75 (75.8) \\
\hline \multirow[t]{2}{*}{ Family history of HCC } & Negative & $87(88)$ \\
\hline & Positive & $12(12)$ \\
\hline \multirow[t]{2}{*}{ Tumor size } & $\leq 3 \mathrm{~cm}$ & $36(36.4)$ \\
\hline & $>3 \mathrm{~cm}$ & $63(63.6)$ \\
\hline \multirow[t]{2}{*}{ No. of focal lesions } & $\leq 3$ & $71(71.7)$ \\
\hline & $>3$ & $28(28.3)$ \\
\hline \multirow[t]{6}{*}{ Stage (TNM classification) } & 1 & $7(7.1)$ \\
\hline & II & 19 (19.2) \\
\hline & IIIA & $30(30.3)$ \\
\hline & IIIB & $15(15.2)$ \\
\hline & IVA & $15(15.2)$ \\
\hline & IVB & $13(13.1)$ \\
\hline \multirow[t]{2}{*}{ Stage } & Early stage (I, II) & $26(26.3)$ \\
\hline & $\begin{array}{l}\text { Late stage (IIIA, IIIB, } \\
\text { IVA, IVB) }\end{array}$ & $73(73.7)$ \\
\hline \multirow[t]{6}{*}{ Child score } & A5 & $21(21.1)$ \\
\hline & A6 & $32(32.4)$ \\
\hline & B7 & $18(18.3)$ \\
\hline & B8 & $10(9.9)$ \\
\hline & B9 & $15(15.5)$ \\
\hline & $\mathrm{C} 1$ & $3(2.8)$ \\
\hline \multirow[t]{2}{*}{ Distant metastasis } & No & $87(86.9)$ \\
\hline & Yes & $12(13.1)$ \\
\hline \multirow[t]{2}{*}{ Liver cirrhosis } & Negative & $2(2.1)$ \\
\hline & Positive & $97(97.9)$ \\
\hline \multirow[t]{2}{*}{ Portal vein } & Thrombosed & $22(25.0)$ \\
\hline & Patent & $77(75.0)$ \\
\hline \multirow[t]{2}{*}{ Splenomegaly } & - ve & $38(38.9)$ \\
\hline & $+\mathrm{ve}$ & $61(61.1)$ \\
\hline \multirow[t]{2}{*}{ Ascites } & Present & $35(35.3)$ \\
\hline & Absent & $64(64.7)$ \\
\hline \multirow[t]{2}{*}{ Lymph node metastasis } & -ve & $76(76.8)$ \\
\hline & $+\mathrm{ve}$ & $23(23.2)$ \\
\hline \multirow[t]{2}{*}{ HBV infection } & B-ve & $96(97.0)$ \\
\hline & $B+v e$ & $3(3.0)$ \\
\hline \multirow[t]{2}{*}{ HCV infection } & C-ve & $16(16.2)$ \\
\hline & $C+$ ve & $83(83.8)$ \\
\hline \multirow[t]{2}{*}{ GSH $(\mu \mathrm{M} / \mathrm{mg})(\mathrm{N}: 684-2525)$} & Median & 1916.5 \\
\hline & Range & $(862-3011)$ \\
\hline
\end{tabular}


Table 2 Comparison between the HCC and the normal control groups as regards the glutathione S-transferase P1 (GSTP1) phenotype

\begin{tabular}{|c|c|c|c|c|c|c|c|}
\hline & & & \multicolumn{2}{|l|}{ Group } & \multirow[t]{2}{*}{$\boldsymbol{p}$ value } & \multirow[t]{2}{*}{ OR } & \multirow[t]{2}{*}{$95 \% \mathrm{Cl}$ for OR } \\
\hline & & & Control (80) & Cases (99) & & & \\
\hline \multirow[t]{3}{*}{ GSTP1 } & AA & $\mathbf{N}(\%)$ & $60(75)$ & $45(45.5)$ & $<0.001$ & & \\
\hline & $\mathrm{GA}$ & $\mathbf{N}(\%)$ & $20(25)$ & $44(44.4)$ & & & \\
\hline & GG & $\mathbf{N}(\%)$ & $0(0.0)$ & $10(10.1)$ & & & \\
\hline \multirow{3}{*}{$\begin{array}{l}\text { Recessive model } \\
\text { (GSTP1) }\end{array}$} & AA & $\mathbf{N}(\%)$ & $60(75)$ & $45(45.5)$ & $<0.001$ & 3.6 & Lower, 1.894 \\
\hline & & & & & & & Upper, 6.843 \\
\hline & GA\&GG & $\mathbf{N}(\%)$ & $20(25)$ & $54(54.4)$ & & & \\
\hline \multirow{2}{*}{$\begin{array}{l}\text { Dominant model } \\
\text { (GSTP1) }\end{array}$} & AA\&AG & $\mathbf{N}(\%)$ & $80(100)$ & $89(89.9)$ & 0.003 & & \\
\hline & GG & $\mathbf{N}(\%)$ & $0(0)$ & $10(10.1)$ & & & \\
\hline \multirow{2}{*}{$\begin{array}{l}\text { GSTP1 } \\
\text { (mutant versus wild) }\end{array}$} & Mutant & N (\%) & $20(25.0)$ & $54(54.5)$ & $<0.001^{*}$ & & \\
\hline & Wild & N (\%) & $60(75)$ & $45(45.5)$ & & & \\
\hline
\end{tabular}

GSTP1 glutathione S-transferase P1

*Significant $p$ value $\leq 0.05$

The comparison of some laboratory markers as ALT, AST, bilirubin, ALP, albumin, AFP, LDH, PT, urea, creatinine, plasma level of GSH, hemoglobin, TLC, and platelet count according to GSTP1 genotype revealed non-significant results except for ALT. The median level of ALT was highest in the homozygous variant group followed by heterozygous variant, lastly, comes the wild type group with medians of $(106.5,51$, and $43.5 \mathrm{U} / \mathrm{L})$ respectively $(p=0.049)$ (Table 6$)$.

Comparison of ALT according to GSTP1 genotype shows a significant difference between the wild and mutant homozygous group ( $p$ value 0.049 ) while a non-significant difference was found between the wild and mutant group ( $p$ value 0.886 ) and between the mutant heterozygous and mutant homozygous groups ( $p$ value 0.162 )

The best sensitivity, specificity, PPV, NPV, and overall diagnostic performance for plasma GSH at a cutoff level of $2003.5 \mu \mathrm{M} / \mathrm{mg}$ and for AFP at a cutoff of $21.5 \mathrm{ng} / \mathrm{ml}$ were $57.6 \%, 52.5 \%, 60 \%, 40 \%$ and $78.8 \%, 100 \%, 100 \%$, $79.2 \%$, respectively. The area under the curve for GSH is 0.562 and for AFP is 0.864 (Figs. 3 and 4).

On performing multivariate analysis for independent prognostic factors in relation to HCC risk, the mutant GSTP1 phenotype had 3.4-fold higher risk than the wild phenotype $[p<0.047$, CI (1.015-11.386)], high serum ALT had 14.910-fold higher risk than low serum ALT $[p<0.001$, CI (4.190-53.053)], male gender had 13.583-fold higher risk than female gender $[(p<0.001$, CI (3.702-49.838)], and older age had 19.329-fold higher risk than younger age $[p<0.001$, CI (5.63366.755)].

GSTP1 gene for control fits the Hardy-Weinberg equilibrium with $p$ value 0.124 .

\section{Discussion}

Because Egypt has the highest prevalence of hepatitis $\mathrm{C}$ virus $\mathrm{HCV}$ worldwide, the burden of HCC has been increasing with a doubled incidence rate in the past 10 years [11].

Continuous oxidative stress has been associated with hepatocarcinogenesis, suggesting that antioxidant treatment may provide some sort of protection against cancer [12].

Since the main action of the oxido-reductive enzymes (superoxide dismutase, catalase, and glutathione peroxidase) that constitute the most important scavenger systems for free radicals is to provide a steady supply of GSH, conjugate GSH with various environmental risk factors [13], as well as to control the action of specific transporters to remove GSH conjugate from the cell [6], a dramatic downregulation of such enzymes has been considered to be a characteristic pathological feature of HCC [14].

Hence, GSTP1 polymorphisms could decrease detoxification when individuals are exposed to HCC risk factors [15] so we hypothesized that GSTP1 polymorphism could be a probable risk factor for the development of HCC.

Also investigating the oxidative stress status of HCC patients by measuring the antioxidant glutathione (GSH) levels and assessing its relation with GSTP1 polymorphism were important objectives of this study.

In this study, $30 \%$ of the normal control and $54.4 \%$ of the HCC groups had mutant GSTP1 genotype, while $70 \%$ of the normal control and $45.5 \%$ of the HCC groups had the wild genotype $(p=0.0005)$.

Consistently, El-Shafie et al. [16] reported a significant difference between the HCC and the control groups regarding GSTP1 genotyping. 
Table 3 Comparison of the plasma levels of reduced glutathione with some prognostic factors of HCC

\begin{tabular}{|c|c|c|c|}
\hline \multirow{3}{*}{ Age (years) } & \multirow{3}{*}{$<54$} & \multirow{3}{*}{$\begin{array}{l}\text { GSH }(\mu \mathrm{M} / \mathrm{mg})(\mathrm{N}: 684-2525) \\
\text { Median (range) } \\
1976(862-3011)\end{array}$} & \multirow{2}{*}{$\begin{array}{l}\text { Adjusted } \\
\boldsymbol{p} \text { value }\end{array}$} \\
\hline & & & \\
\hline & & & 0.885 \\
\hline Age (years) & $\geq 55$ & $1861(952-3000)$ & \\
\hline \multirow[t]{2}{*}{ Gender } & Female & $1861(877-2625)$ & 0.403 \\
\hline & Male & $1952(862-3011)$ & \\
\hline \multirow[t]{3}{*}{ Tumor size $(\mathrm{cm})$} & 3 & $2013(990-2409)$ & 0.891 \\
\hline & Less than 3 & 1952 (877-2720) & \\
\hline & More than 3 & $1877(862-3011)$ & \\
\hline \multirow[t]{2}{*}{ No. of masses } & $\leq 3$ & $1921(867-3000)$ & 0.669 \\
\hline & $>3$ & $1889(862-3011)$ & \\
\hline \multirow[t]{2}{*}{ Stage } & Early stage & 1961 (867-3000) & 0.778 \\
\hline & Late stage & $1912(862-3011)$ & \\
\hline \multirow[t]{3}{*}{ Child score } & A & 1991 (952-3000) & $0.043^{*}$ \\
\hline & B & $1952(862-2720)$ & \\
\hline & $\mathrm{C}$ & $941(894-987)$ & \\
\hline \multirow[t]{2}{*}{ Distant metastasis } & No & 1919 (867-3011) & 0.333 \\
\hline & Yes & $1247(862-2931)$ & \\
\hline \multirow[t]{2}{*}{ Liver cirrhosis } & Negative & $2568(2124-3011)$ & * \\
\hline & Positive & $1912(862-3000)$ & \\
\hline \multirow[t]{2}{*}{ Portal vein } & Thrombosed & 1689 (894-2911) & 0.859 \\
\hline & Patent & $1988(862-3011)$ & \\
\hline \multirow[t]{2}{*}{ Splenomegaly } & -ve & $1746(910-3000)$ & 0.455 \\
\hline & +ve & $2003(862-3011)$ & \\
\hline \multirow[t]{2}{*}{ Ascites } & Present & $1731(862-2416)$ & $0.043^{*}$ \\
\hline & Absent & $1952(922-3011)$ & \\
\hline \multirow[t]{2}{*}{ L.Ns } & -ve & $1914(862-3011)$ & 0.369 \\
\hline & +ve & 2061 (899-2931) & \\
\hline \multirow[t]{2}{*}{ Family history of HCC } & Negative & $1912(862-3011)$ & 0.448 \\
\hline & Positive & $2000(992-2911)$ & \\
\hline \multirow[t]{2}{*}{ HBV infection } & B-ve & $1906(862-3011)$ & 0.237 \\
\hline & $B+v e$ & $2101(2003-2573)$ & \\
\hline \multirow[t]{2}{*}{ HCV infection } & C-ve & 1838 (910-3011) & 0.905 \\
\hline & $C+v e$ & $1921(862-3000)$ & \\
\hline \multirow[t]{3}{*}{ GSTP1 homo hetero vs wild } & Mutant heterozygous & $1991(877-2911)$ & 0.198 \\
\hline & Mutant homozygous & $1508(894-2241)$ & \\
\hline & Wild & $1851(862-3011)$ & \\
\hline \multirow[t]{2}{*}{ GSTP1 wild vs mutant } & Mutant & 1964 (877-2911) & 0.569 \\
\hline & Wild & $1851(862-3011)$ & \\
\hline
\end{tabular}

Median and range in parenthesis

Significant $p$ value $\leq 0.05$

GSH reduced glutathione, GSTP1 glutathione S-transferase P1

*No $p$ value calculated because of small sample size 
Table 4 Comparison between the HCC and the normal control groups as regards different laboratory markers and plasma GSH

\begin{tabular}{|c|c|c|c|c|c|}
\hline \multirow[t]{2}{*}{ Group } & \multicolumn{2}{|l|}{ Control } & \multicolumn{2}{|l|}{ Patient } & \multirow[t]{2}{*}{$\boldsymbol{p}$ value } \\
\hline & Median & Range & Median & Range & \\
\hline $\begin{array}{l}\mathrm{ALT}(\mathrm{U} / \mathrm{L}) \\
\mathrm{N} \text { : up to } 41\end{array}$ & 25 & $21: 30.8$ & 51 & $35: 67.5$ & $<0.001^{*}$ \\
\hline $\begin{array}{l}\text { AST (U/L) } \\
\mathrm{N}: \text { up to } 40\end{array}$ & 26 & $20: 30$ & 82 & $54: 114$ & $<0.001^{*}$ \\
\hline $\begin{array}{l}\text { ALP (U/L) } \\
\text { N: up to } 279\end{array}$ & 92.25 & $82: 104.8$ & 175 & $127: 248$ & $<0.001^{*}$ \\
\hline $\begin{array}{l}\text { ALB (g/dl) } \\
\text { N: } 3.5: 5.2\end{array}$ & 4 & $3.9: 4.2$ & 3.27 & $2.8: 3.5$ & $<0.001^{*}$ \\
\hline $\begin{array}{l}\text { INR } \\
\text { N: up to } 1\end{array}$ & 1 & $1: 1$ & 1.24 & $1.1: 1.3$ & $<0.001^{*}$ \\
\hline $\begin{array}{l}\text { UREA (mg/dl) } \\
\mathrm{N}: 15-45\end{array}$ & 31 & $28: 36$ & 28 & $22: 34.5$ & $0.007^{*}$ \\
\hline $\begin{array}{l}\text { AFP (ng/ml) } \\
\mathrm{N}: \text { up to } 10.5\end{array}$ & 1.85 & $1.2: 2.7$ & 117 & 16.3:1559.8 & $<0.001^{*}$ \\
\hline $\begin{array}{l}\mathrm{LDH}(\mathrm{U} / \mathrm{L}) \\
\mathrm{N} \text { : up to } 250\end{array}$ & 116.5 & 102.3:130 & 207 & $172: 248$ & $<0.001^{*}$ \\
\hline $\begin{array}{l}\mathrm{HB}(\mathrm{gm} / \mathrm{dl}) \\
\mathrm{N}: \text { Male }(13: 18) \\
\text { Female }(12: 16)\end{array}$ & 12.3 & 11.1:13.4 & 13 & $12: 14$ & $0.001^{*}$ \\
\hline $\begin{array}{l}\mathrm{TLC}^{*} 10 \wedge 9 / \mathrm{L} \\
\mathrm{N}: 4-11\end{array}$ & 7.3 & $5.9: 8.2$ & 5.3 & $4.2: 6.9$ & $<0.001^{*}$ \\
\hline $\begin{array}{l}P L T^{*} 10 \wedge 9 / L \\
N: 150-400\end{array}$ & 226.5 & 194.3:280.8 & 125 & $81: 195$ & $<0.001^{*}$ \\
\hline $\begin{array}{l}\text { GSH }(\mathrm{mM} / \mathrm{mg}) \\
\mathrm{N}: 684-2525\end{array}$ & 2010 & 1619.8:2310.8 & 1916.5 & $(862-3011)$ & 0.152 \\
\hline
\end{tabular}

INR international normalization ratio, ALT alanine aminotransferase, AST aspartate aminotransferase, $L D H$ lactate dehydrogenase, AFP alpha feto protein, $A L P$ alkaline phosphatase, GSH reduced glutathione, $A L B$ albumin, $H B$ hemoglobin, $T L C$ total leucocytic count, PLT platelets

*Significant $p$ value $\leq 0.05$

Also, Munaka et al. [17] detected the expression of mutant GSTP1 genotype in $33.3 \%$ and $23.1 \%$ and the wild genotype in $66.7 \%$ and $76.9 \%$ in the normal control and HCC groups respectively among the Japanese patients.

Mutant type of GSTP1, older age, male gender, and high serum alanine aminotransferase (ALT) were found to be significant independent prognostic factors for HCC risk in this study $(p<0.047,<0.001,<0.001$ and $<$ 0.001 ), respectively, which is contradictory to the results of Chen et al. [10], who found that individuals aged $\leq$ 57 years with AG or GG alleles of GSTP1 had a (2.18 and 5.64) fold risk of developing HCC compared to individuals with AA alleles ( $p=0.02$ and 0.04$)$ respectively, but no association was found in the older group aged > 57 years. In the present study, patients and control subjects were selected below the age of 57 as we wanted to compare our patient's population with the group studied by Chen el al [10].

Lu et al. [18] stated that the younger the age, the more likelihood for the exposure to HCC risk factors thus increasing the susceptibility to develop HCC. Since cirrhosis caused by hepatitis $C$ virus infection is the most important predisposing factor for HCC in Egypt, the development of $\mathrm{HCC}$ can occur at a relatively older age as cirrhosis takes relatively long duration to turn into HCC.

On the contrary, Zhao et al. [19], found no association between GSTP1 polymorphism and HCC risk. Subgroup analyses by ethnicity showed no significant association between GSTP1 polymorphism and HCC risk among Asians [19] and Japanese people [17], and decreased risk among Europeans [14], while no association was detected among Chinese people who were exposed to high levels of aflatoxin B1 [20].

On studying the association between GSTP1 polymorphism and the clinical status of the HCC patients the only significant association detected with PVT $(p=0.00783)$.

Consistently, Chen et al. [10] found no association between the estimated clinico-pathological characteristics in HCC patients and gene polymorphisms of GSTP1.

ALT level was also found to be affected by GSTP1 phenotype $(p=0.049)$. The highest concentrations were detected among the mutant homozygous, followed by the mutant heterozygous, then the wild phenotype groups $(p=0.049)$. 
Table 5 Association of the different genotypes of glutathione S-transferase P1 with some prognostic factors of HCC using chi-square test

\begin{tabular}{|c|c|c|c|c|c|c|}
\hline & & \multicolumn{3}{|c|}{ GSTP1 homo hetero vs wild } & \multirow[t]{3}{*}{$\boldsymbol{p}$ value } & \multirow{3}{*}{$x^{2}$} \\
\hline & & Heterozygous variant & Homozygous variant & Wild & & \\
\hline & & $\boldsymbol{N}(\%)$ & $\boldsymbol{N}(\%)$ & $\boldsymbol{N}(\%)$ & & \\
\hline \multirow[t]{2}{*}{ Age (years) } & $<54$ & $20(45.5)$ & $8(80)$ & $23(51.1)$ & 0.142 & 3.899 \\
\hline & $\geq 55$ & $24(54.5)$ & $2(20)$ & $22(48.9)$ & & \\
\hline \multirow[t]{2}{*}{ Gender } & Female & $13(29.5)$ & $1(10.0)$ & $10(10.0)$ & 0.391 & 1.878 \\
\hline & Male & $31(70.5)$ & $9(90.0)$ & $35(77.8)$ & & \\
\hline \multirow[t]{2}{*}{ Tumor size } & $\leq 3 \mathrm{~cm}$ & $16(36.4)$ & $4(40.0)$ & $16(35.6)$ & 0.966 & 0.070 \\
\hline & $>3 \mathrm{~cm}$ & $28(63.6)$ & $6(60.0)$ & $29(64.4)$ & & \\
\hline \multirow[t]{4}{*}{ No. of focal lesions } & 1 & $24(54.5)$ & $4(40.0)$ & $23(51.1)$ & 0.286 & 0.381 \\
\hline & 2 & $3(6.8)$ & $3(30.0)$ & $8(17.8)$ & & \\
\hline & 3 & $4(9.1)$ & $1(10.0)$ & $1(2.2)$ & & \\
\hline & More than 3 & $13(29.5)$ & $2(20.0)$ & $13(28.9)$ & & \\
\hline \multirow[t]{2}{*}{ Stage } & Early stage (I, II) & $12(27.3)$ & $3(30.0)$ & $11(24.4 .0)$ & 0.918 & 0.172 \\
\hline & Late stage (III, IV) & $32(72.7)$ & $7(70.0)$ & $34(75.6)$ & & \\
\hline \multirow[t]{3}{*}{ Child score } & A & $23(53.3)$ & $8(80.0)$ & $26(57.8)$ & & \\
\hline & B & $21(47.7)$ & $1(10.0)$ & $18(40.0)$ & & \\
\hline & $\mathrm{C}$ & $0(0)$ & $1(10.0)$ & $1(2.2)$ & & \\
\hline \multirow[t]{2}{*}{ Distant metastasis } & No & $42(95.5)$ & $8(8.1)$ & $36(36.4)$ & 0.077 & 5.118 \\
\hline & Yes & $2(4.5)$ & $2(2.0)$ & $9(9.1)$ & & \\
\hline \multirow[t]{2}{*}{ Liver cirrhosis } & Negative & $1(2.3)$ & $0(0.0)$ & $1(2.2)$ & & \\
\hline & Positive & $43(97.7)$ & $10(100.0)$ & $44(97.8)$ & & \\
\hline \multirow[t]{2}{*}{ Portal vein } & Thrombosed & $6(13.6)$ & $6(60.0)$ & $8(17.8)$ & 0.004 & 9.700 \\
\hline & Patent & $38(86.4)$ & $4(40.0)$ & $37(82.2)$ & & \\
\hline \multirow[t]{2}{*}{ Splenomegaly } & $-v e$ & $15(34.1)$ & $5(50.0)$ & $17(37.8)$ & 0.642 & 2.037 \\
\hline & $+\mathrm{ve}$ & $29(65.9)$ & $5(50.0)$ & $28(62.2)$ & & \\
\hline \multirow[t]{2}{*}{ Ascites } & Present & $16(36.4)$ & $4(40.0)$ & $20(44.4)$ & 0.739 & 0.292 \\
\hline & Absent & $28(63.6)$ & $6(60.0)$ & $25(55.6)$ & & \\
\hline \multirow[t]{2}{*}{ L.Ns } & $-v e$ & 39 (88.6) & $8(80.0)$ & $26(57.8)$ & 0.004 & 4.905 \\
\hline & $+\mathrm{ve}$ & $5(11.4)$ & $2(20.0)$ & $19(42.2)$ & & \\
\hline \multirow[t]{2}{*}{ Family history of HCC } & Negative & $37(84.1)$ & $7(70.0)$ & $43(95.6)$ & 0.048 & 5.286 \\
\hline & Positive & $7(15.9)$ & $3(30.0)$ & $2(4.4)$ & & \\
\hline \multirow[t]{2}{*}{ HBV infection } & B-ve & $42(95.5)$ & $10(100.0)$ & $44(97.8)$ & * & \\
\hline & $B+v e$ & $2(4.5)$ & $0(0.0)$ & $1(2.2)$ & & \\
\hline \multirow[t]{2}{*}{ HCV infection } & C-ve & $6(13.6)$ & $0(0.0)$ & $10(22.2)$ & 0.187 & 3.355 \\
\hline & $C+$ ve & 38 (86.4) & $10(100.0)$ & 35 (77.8) & & \\
\hline
\end{tabular}

Significant $p$ value $\leq 0.05$

Number and percentage in parenthesis

GSTP1 glutathione S-transferase P1, GSTP1 glutathione S-transferase P1

${ }^{*} p$ value cannot be assessed due to small number

*Significant $p$ value $\leq 0.05$

Similarly, Mannaa et al. [21] found that increased serum levels of AST and ALT were highly correlated with the increased expression of GSTP1. On the other hand, Chen et al. [10] and Li et al. [22] found nonsignificant associations between genetic polymorphisms of GSTP1 and both ALT and AST.
ALT can produce pyruvate and L-glutamate by reversibly catalyzing the transfer of an amino group from Lalanine to $\alpha$-ketoglutarate. L-glutamic acid, glycine, and L-cysteine are the amino acids needed for glutathione synthesis in the body. That is how ALT activity can affect the glutathione concentration inside the body [23]. 
Table 6 Comparison of some laboratory markers according to GSTP1 genotype

\begin{tabular}{|c|c|c|c|c|}
\hline & Heterozygous variant & Homozygous variant & Wild & $\boldsymbol{p}$ value \\
\hline & Median (range) & Median (range) & Median (range) & \\
\hline ALT (U/L) (up to 45) & $51.0(23-135)$ a & $106.50(54-181) b$ & $43.50(9-150) c$ & $0.049^{*}$ \\
\hline ALB (g/dl) (3.5:5.2) & $3.30(1.8-4.87)$ & $3.1(2.7-4.2)$ & $3.1(2.2-4.3)$ & 0.579 \\
\hline $\mathrm{PLT}^{*} 10 \wedge 9 / \mathrm{L}(150-400)$ & $101.5(50-260)$ & $102.5(63-244)$ & $120.000(28-365)$ & 0.422 \\
\hline AST (U/L) (up to 41 ) & 79 (19.8-208) & $69.5(30-229)$ & $73(10-508)$ & 0.698 \\
\hline BIL (mg/dl) (up to 1.1) & $1.2(0.7-3.82)$ & $1.3(0.2-5.8)$ & $1.2(0.5-4.9)$ & 0.684 \\
\hline ALP (U/L) (up to 279) & $165(70-713)$ & $207.0(85-900)$ & $150.0(57-808)$ & 0.543 \\
\hline INR (up to 1) & $1.21(1-2.5)$ & $1.2(1.00-1.31)$ & $1.2(1-1.8)$ & 0.486 \\
\hline Creatinine (mg/dl) $(0.7-1.4)$ & $0.9(0.6-1.5)$ & $1(0.80-1.2)$ & $0.9(0.5-1.84)$ & 0.835 \\
\hline UREA (mg/dl) (15-45) & $30(17-60)$ & $32(19-50)$ & $32(17-71)$ & 0.363 \\
\hline AFP (ng/ml) (up to 10.5) & $103.4(4.938295)$ & $580.8(2.3-155449)$ & $165(2.3-126817)$ & 0.144 \\
\hline LDH (U/L) (up to 250 ) & $190(88-331)$ & $209.5(101-330)$ & $206(105-303)$ & $0.012^{*}$ \\
\hline $\begin{array}{l}\text { HB (gm/dl) } \\
\text { N: Male (13:18) } \\
\text { Female (12:16) }\end{array}$ & $12.4(8.2-15.7)$ & $11.4(9.3-14.8)$ & $12.5(8.9-15.9)$ & 0.835 \\
\hline TLC*10^9/L (4.0:11.0) & $4.7(2.5-13.9)$ & $4.6(2.5-10.065)$ & $4.8(10.2-12.87)$ & 0.683 \\
\hline GSH $(\mu \mathrm{M} / \mathrm{mg})(684-2525)$ & $2000(877-2911)$ & $1507.5(894-2241)$ & $1851(862-3011)$ & 0.208 \\
\hline PC (\%) & $0.8(0.4-79.5)$ & $0.8(0.7-1)$ & $0.8(0.5-67.5)$ & 0.867 \\
\hline
\end{tabular}

Median and range in parenthesis

Significant $p$ value $\leq 0.05$

INR international normalization ratio, $P C$ prothrombin concentration, $A L T$ alanine aminotransferase, AFP alpha feto protein, GSH reduced glutathione, AST aspartate aminotransferase, $A L P$ alkaline phosphatase, $A L B$ albumin, $L D H$ lactate dehydrogenase

${ }^{*}$ Cannot be measured due to small no. of values

a, $C$ non-significant ( $p$ value 0.886$)$

$b, C$ significant ( $p$ value 0.049 )

c, B non-significant ( $p$ value 0.162 )
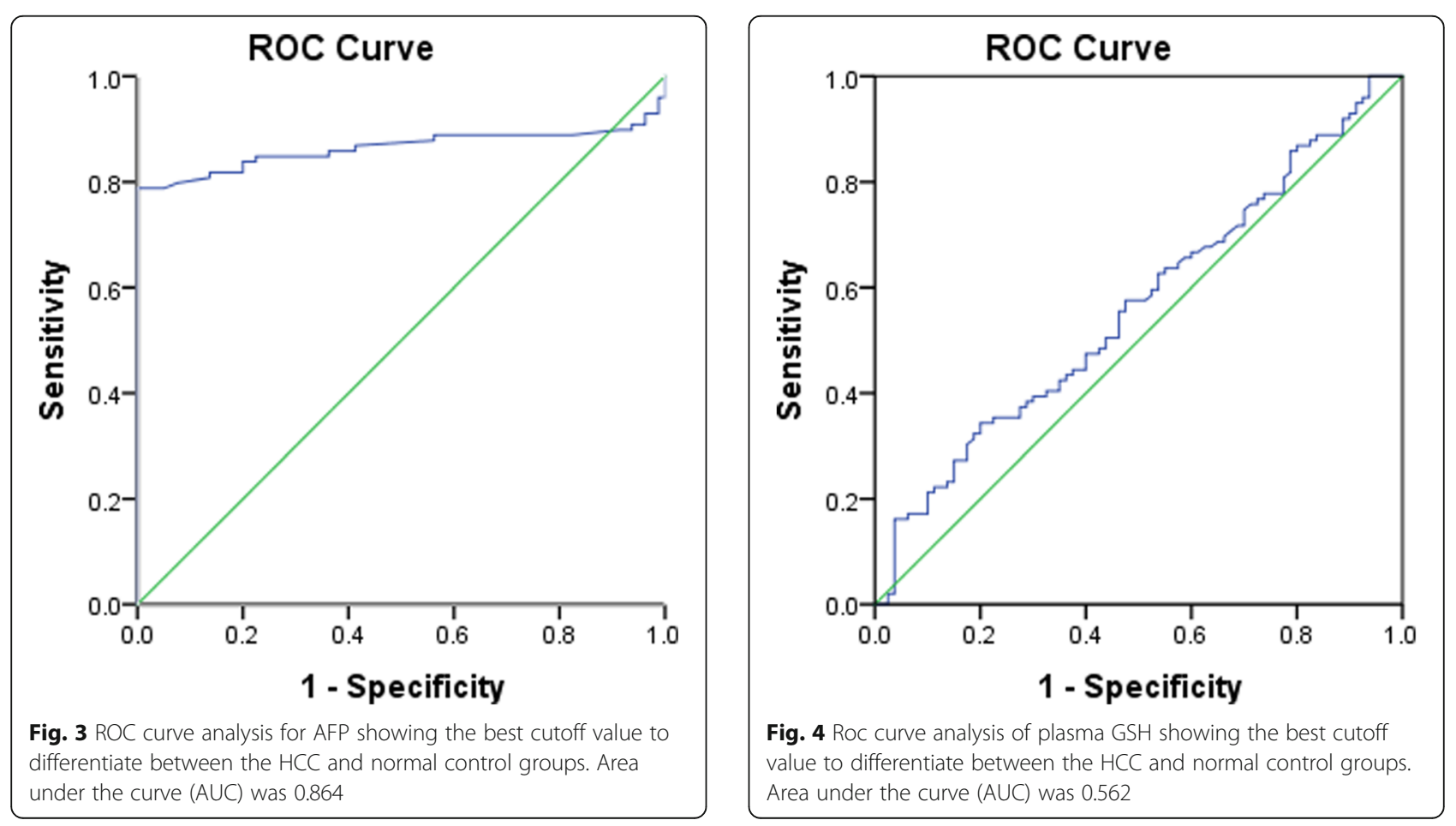
During inflammation, GSH released from hepatocytes can detoxify reactive oxygen species (ROS) generated in the vascular space of the liver. However, diffusion of the ROS into hepatocytes can result from excessive ROS formation. This can lead to intracellular oxidant stress that can activate a series of transcription factors which can induce 500 genes' expression; some of which could contribute to carcinogenesis [24] and can cause cell injury through mitochondrial dysfunction [25].

A higher level of GSH has got two contradictory actions: it is important for normal cellular functions, signal transduction, and protection against certain carcinogens, but at the same time can slow down any cancer therapy that works by increasing intracellular reactive oxygen species [25].

On the other hand, although an increase in the ROS in cancer cells is part of the carcinogenesis process, such excessive levels of the ROS can also be toxic to the cancer cells. Therefore, controlling the levels of intrinsic ROS by GSH modulation can be an effective way to selectively kill cancer cells without adversely affecting normal cells [26].

Considering the important role of GSTP-1 in the antioxidant defense mechanism, we further measured the levels of glutathione being an important antioxidant. Although the plasma levels of glutathione were lower in the HCC compared to the normal control group in this study, the comparison did not reach statistical significance $(p=0.156)$. We also could not find any significant relation between GSTP1 polymorphism and the plasma level of GSH ( $p$ value 0.569 ).

Consistently, Tsaiel al [27]. reported that the levels of GSH were significantly lower in patients with hepatitis B virus (HBV)-associated $\mathrm{HCC}$ than in the control group. Also, Czeczot el al [28]. found that GSH level was lower in malignant tissues compared to adjacent normal tissues.

Similarly, Li et al. [22] found that plasma GSH and GST levels were statistically lower in HCC patients than in chronic hepatitis $\mathrm{C}(\mathrm{CHB})$ patients. These results indicated that HCC patients are under more severe imbalance of oxidants and antioxidants than patients with benign liver conditions [24].

On the contrary, Huang et al. [4] demonstrated that GSH levels were doubled in the HCC compared to the normal group and Li et al. [22] found that GSTP1 protein expression level was significantly correlated with GSH concentration $(p<0.01)$.

We found that GSH concentration was highest in patients with Child score A, and patients with no ascites ( $p=0.043)$ each. This might be due to the severe imbalance of oxidative stress and antioxidant defense among the patients with advanced disease status.

We could not find any significant relation between GSTP1 polymorphism and alpha-fetoprotein level in serum $(p=0.812)$. Similarly, Chen et al. [10] found no association between the gene polymorphism of GSTP1 and AFP.

Up to our knowledge, the clinical utility of the plasma GSH level in HCC was not previously studied. So, we tried to test for the validity of plasma GSH to be used as a diagnostic marker for HCC.

GSH and AFP showed sensitivity and specificity of $(38 \%, 53 \%)$ and $(79 \%, 94 \%)$ respectively. So, plasma levels of glutathione cannot be considered a probable candidate marker for the diagnosis of HCC; however, further studies with larger groups of population are recommended to validate such results.

Yusof et al. [29] estimated the sensitivity of AFP in HCC as $36.7 \%$ compared to $53.3 \%$ for GSTP1, thus making GSTP1 a more sensitive marker for detection of HCC.

\section{Conclusions}

The prevalence of mutant GSTP1 was higher among the HCC patients compared to the normal control group, which might nominate GSTP1 to be a probable marker for screening of HCC among the highly susceptible individuals.

Based on our data, the mutant GSTP1 phenotype, older age, male gender, and high serum ALT are associated with an increased risk of HCC development. Thus, GSTP1 gene polymorphism is recommended to be incorporated in the risk assessment model which would allow early diagnosis, better management, and use of probable targeted therapy in selected patients.

Further studies with larger numbers of patients are recommended to validate these results.

\section{Abbreviations}

HCC: Hepatocellular carcinoma; GSH: Reduced glutathione; GSTP1: Glutathione S-transferase P1; PCR-RFLP: Polymerase chain reactionrestriction fragment length polymorphism; PVT: Portal vein thrombosis; ALT: Alanine aminotransferase; GSSG: Oxidized glutathione; GSR: Glutathione reductase; GSTs: Glutathione S-transferases; ROC: Receiver operating characteristics; ROS: Reactive oxygen species; DNA: Deoxyribonucleic acid; PCR: Polymerase chain reaction; AST: Aspartate aminotransferase; ALP: Alkaline phosphatase; PPV: Positive predictive value; NPV: Negative predictive value

\section{Acknowledgements \\ Not applicable.}

\section{Authors' contributions}

SE: Performing the practical part, the writing and editing of the thesis. NS: Supervising the molecular biology practical part and revision. NR: Revising the writing of the thesis. OM: Providing the samples, clinical data, and revision. RA: Doing the statistical analysis. SS: Helping in the practical part. IA: (Principal investigator) Director of the lab, idea of research, guiding, revision, and performing statistical analysis. All authors have read and approved the manuscript.

Funding

No funding 


\section{Availability of data and materials \\ Available}

\section{Ethics approval and consent to participate}

The study was approved from the ethical committee of the National Cance Institute NCl, Cairo University (Organization no. 0003381) under the number of 00004025 with a Federalwide Assurance (FWA) number 00007284 as well as the National Liver Institute-Shebein El-kawm-El-Monofeya. Written informed consent was obtained from all participants prior to inclusion in the study.

This work was carried out in accordance with the Declaration of Helsinki for experiments involving humans.

\section{Consent for publication}

Not applicable

\section{Competing interests}

No conflict of interest.

\section{Author details}

${ }^{1}$ The Department of Clinical Pathology, Elkhanka Central Hospital, Qualiobeya, Egypt. ${ }^{2}$ The Department of Clinical and Chemical Pathology, NCI, Cairo, Egypt. ${ }^{3}$ The Department of Medical Oncology, NCl, Cairo, Egypt. ${ }^{4}$ The Department of Biostatistics and Cancer Epidemiology, $\mathrm{NCl}$, Cairo, Egypt. ${ }^{5}$ The Department of Cancer Biology, NCl, Cairo, Egypt.

Received: 22 October 2019 Accepted: 24 August 2020

Published online: 02 October 2020

\section{References}

1. Global cancer statistics 2018: GLOBOCAN estimates of incidence and mortality worldwide for 36 cancers in 185 countries.

2. Elghazaly H, Gaballah A, Bahie Eldin N, et al. Annals of Oncology. 2018; 29(suppl 5):mdy151.018.

3. Nishikawa T, Nakajima T, Katagishi T, Okada Y, Jo M, Ketal K. Oxidative stress may enhance the malignant potential of human hepatocellular carcinoma by telomerase activation. Liver Int. 2009;29:846-56.

4. Huang ZZ, Chen C, Zeng Z, Yang H, Oh J, Chen L, et al. Mechanism and significance of increased glutathione level in human hepatocellular carcinoma and liver regeneration. FASEB J. 2000. https://doi.org/10.1096/fj. 00-0445fje.

5. Couto N, Malys N, Gaskell SJ, Barber J. Partition and turnover of glutathione reductase from Saccharomyces cerevisiae: a proteomic approach. J Proteome Res. 2013;12(6):2885-94.

6. Kweekel DM, Koopman M, Antonini NF, Van der Straaten T, Nortier JWR, Gelderblom H, et al. GSTP1 Ile105Val polymorphism correlates with progression-free survival in MCRC patients treated with or without irinotecan: a study of the Dutch Colorectal Cancer Group. Br J Cancer. 2008; 99:1316-21.

7. Reszka E, Jabłonowski Z, Wieczorek E. GSTP1 mRNA expression in human circulating blood leukocytes is associated with GSTP1 genetic polymorphism. Clin Bio Chem. 2011;44:1153-5.

8. Lee JM, Wu MT, Lee YC, Yang SY, Chen JS, Hsu HH, et al. Association of GSTP1 polymorphism and survival for esophageal cancer. Clin Cancer Res. 2005; 11:4749-53.

9. Ellman GL. Tissue sulfhydryl groups. Arch Biochem Biophys. 1959;82:70-7.

10. Chen $Y$, Tseng H, KuoW YS, ChenEmail D, Ting H. Glutathione S-transferase P1 (GSTP1) gene polymorphism increases age-related susceptibility to hepatocellular carcinoma. BMC Med Genet. 2010;11:46.

11. Gomaa Al, Khan SA, Toledano MB, Waked I, Taylor-Robinson SD. Hepatocellular carcinoma: epidemiology, risk factors and pathogenesis. World J Gastroenterol. 2008;14(27):4300-8.

12. Cabello CM, Bair WB 3rd, Wondrak GT. Experimental therapeutics: targeting the redox Achilles heel of cancer. Curr Opin Investig Drugs. 2007;8(12): 1022-37.

13. Pearson WR. Phylogenies of glutathione transferase families. Methods Enzymol. 2005:401:186-204.

14. Marra M, Sordelli IM, Lombardi A, Lamberti M, Tarantino L, Giudice A, et al. Molecular targets and oxidative stress biomarkers in hepatocellular carcinoma: an overview. J Transl Med. 2011;10:171.
15. Ping J, Wang H, Huang M, Liu ZS. Genetic analysis of glutathione Stransferase A1 polymorphism in the Chinese population and the influence of genotype on enzymatic properties. Toxicol Sci. 2006;89(2):438-43.

16. El Shafie MK, Shebl N, El-Sabwaay M, Abbas S, Kamal S. Glutathione-Stransferase (GSTP1) gene polymorphism and susceptibility to hepatocellular carcinoma in Egypt. Egyptian J Biochem Mol Biol. 2014;32:1.

17. Munaka M, Kohshi K, Kawamoto T, Takasawa S, Nagata N, Itoh H, et al. Genetic polymorphisms of tobacco- and alcohol-related metabolizing enzymes and the risk of hepatocellular carcinoma. J Cancer Res ClinOncol. 2003;129(6):355-60.

18. Lu SN, Su WW, Yang SS, Chang TT, Cheng KS, Wu JC, et al. Secular trends and geographic variations of hepatitis $B$ virus and hepatitis $C$ virusassociated hepatocellular carcinoma in Taiwan. Int J Cancer. 2006;119(8): 1946-52.

19. Zhao Y, Wang Q, Deng X, Shi P, Wang Z. Quantitative assessment of the association between GSTP1 gene lle105Val polymorphism and susceptibility to hepatocellular carcinoma. Tumour Biol. 2013;34(4):2121-6.

20. McGlynn KA, Hunter K, Le Voyer T, Roush J, Wise P, et al. Susceptibility to aflatoxin B1-related primary hepatocellular carcinoma in mice and humans. Cancer Res. 2003;63(15):4594-601.

21. Mannaa F, Ahmed HH, Estefan SF, Sharaf HA, Eskander EF. Saccharomyces cerevisiae intervention for relieving flutamide-induced hepatotoxicity in male rats. Pharmazie. 2005;60(9):689-95

22. Li T, Zhao X-P, Wang L-Y, Gao S, Zhao J, Fan YC, Wang K. Glutathione Stransferase P1 correlated with oxidative stress in hepatocellular carcinoma. Int J Med Sci. 2013;10(6):683-90.

23. Wang CS, Chang TT, Yao WJ, Wang ST, Chou P. Impact of increasing alanine aminotransferase levels within normal range on incident diabetes. J Formos Med Assoc. 2012;111(4):201-8.

24. Reuter S, Gupta SC, Chaturvedi MM, Aggarwal BB. Oxidative stress, inflammation, and cancer: how are they linked? Free RadicBiol Med. 2010; 49(11):1603-16.

25. Abdalla MY. Glutathione as potential target for cancer therapy; more or less is good? (mini-review). Jordan J Biol Sci. 2011;4(3):119-24 ISSN 1995-6673.

26. Trachootham D, Alexandre J, Huang P. Targeting cancer cells by ROSmediated mechanisms: a radical therapeutic approach? Nat Rev Drug Discov. 2009;8(7):579-91.

27. Tsai SM, Lin SK, Lee KT, Hsiao JK, Huang JC, Wu SH, et al. Evaluation of redox statuses in patients with hepatitis B virus-associated hepatocellular carcinoma. Ann Clin Biochem. 2009;46(Pt 5):394-400.

28. Czeczot H, Scibior D, Skrzycki M, Podsiad M. Glutathione and GSH dependent enzymes in patients with liver cirrhosis and hepatocellular carcinoma. Acta Biochim Pol. 2006;53(1):237-42.

29. Yusof YA, Yan KL, Hussain SN. Immunohistochemical expression of pi class glutathione S-transferase and alpha-fetoprotein in hepatocellular carcinoma and chronic liver disease. Anal Quant CytolHistol. 2003;25(6):332-8.

\section{Publisher's Note}

Springer Nature remains neutral with regard to jurisdictional claims in published maps and institutional affiliations.

\section{Submit your manuscript to a SpringerOpen ${ }^{\circ}$ journal and benefit from:}

- Convenient online submission

- Rigorous peer review

- Open access: articles freely available online

- High visibility within the field

- Retaining the copyright to your article

Submit your next manuscript at $>$ springeropen.com 